\title{
Bone changes caused by experimental Solanum malacoxylon poisoning in rabbits ${ }^{1}$
}

\author{
José Ignacio Aguirre ${ }^{2,3}$, María Soledad Gomar ${ }^{2}$, Silvio Igal ${ }^{3}$, María Alejandra \\ Quiroga ${ }^{2}$, Enrique Leo Portiansky ${ }^{2}$ and Eduardo Juan Gimeno ${ }^{2 *}$
}

\begin{abstract}
Aguirre J.I., Gomar M.S., Igal, S., Quiroga M.A., Portiansky E.L \& Gimeno E.J. 2005. Bone changes caused by experimental Solanum malacoxylon poisoning in rabbits. [Alterações ósseas causadas na intoxicação experimental por Solanum malacoxylon em coelhos.] Pesquisa Veterinária Brasileira 25(1):34-38. Institute of Pathology "Prof. Dr. Bernardo Epstein", School of Veterinary Sciences, National University of La Plata, P.O.Box 296, (1900) La Plata, Argentina. E-mail: ejgimeno@fcv.unlp.edu.ar

The aim of this study was to describe the bone changes observed after a daily oral administration of the calcinogenic plant Solanum malacoxylon (syn. S. glaucophyllum) (Sm) during 9 days. The $\mathrm{Sm}$-poisoned rabbits had an increase of bone resorption in the endosteal surface of the cortical zone and also in the surface covered by osteoblasts of the primary and secondary spongiosa of the trabecular bone compartment. Moreover, the epiphyseal growth plates in long bones appeared narrower than in the control rabbits, with reduction of the proliferative and hyperthrophic chondrocyte zones. The electron microscopic study revealed a significant decrease of proteoglycans in the hyperthrophic chondrocyte zone evidenced by a significant reduction of rutenium red positive granules in the poisoned rabbit. Altogether, these data suggest that cell differentiation may play a pivotal role in the pathogenesis of Sm-induced bone lesions.
\end{abstract}

INDEX TERMS: Solanum malacoxylon, S. glaucophyllum, calcinogenic plant, rabbit, bone tissue, growth plate.

\section{INTRODUCTION}

Solanum malacoxylon (Sm) (syn. S. glaucophyllum) is a calcinogenic plant responsible for producing the Enzootic Calcinosis of cattle and sheep in Argentina, Brazil, Paraguay and Uruguay. The disease is characterized by the calcification of soft tissues, especially aorta, heart, lungs, and kidneys (Worker \& Carrillo 1967, Puche \& Bingley 1995, Tokarnia et al. 2000). The plant is highly toxic for cattle and causes considerable economic losses in one of the most important meat production areas of Argentina (Okada et al. 1977). Grazing animals in other parts of the world develop a similar disease but induced by other calcinogenic plants (Morris 1978, Jubb et al. 1993).

${ }^{1}$ Received on May 25, 2004.

Accepted for publication on September 10, 2004.

${ }^{2}$ Institute of Pathology "Prof. Dr. Bernardo Epstein”, School of Veterinary Sciences, National University of La Plata. P.O.Box 296, (1900) La Plata. *Author for correspondence. E-mail: ejgimeno@fcv.unlp.edu.ar

${ }^{3}$ Department of Electron Microscopy, School of Veterinary Sciences, National University of La Plata, P.O.Box 296, (1900) La Plata, Argentina.
Sm contains high levels of 1,25-dihydroxyvitamin $\mathrm{D}_{3}$ $\left(1,25(\mathrm{OH})_{2} \mathrm{D}_{3}\right)$ as glycoside derivatives (Wasserman et al. 1976). In fact, $\mathrm{Sm}$ contains not only $1,25(\mathrm{OH})_{2} \mathrm{D}_{3}$ but also other metabolites, like vitamin $\mathrm{D}_{3}$ and $25(\mathrm{OH}) \mathrm{D}_{3}$ (Esparza et al. 1982).

Bone changes have been studied in natural occurring and experimentally induced calcinosis. Increased bone formation (Döbereiner \& Dämmrich 1974) and osteosclerosis (Krook et al. 1975) have been reported in spontaneous disease. Fibrosis of the bone marrow, endosteal and periosteal hyperostosis, and abnormal formation of ground substance by osteoblasts and fibroblasts were also recorded (Dämmrich et al. 1975).

It has been shown that bone tissue responds differently when a calcinogenic plant is administered. It has been suggested that the diversity of responses may depend upon exposure time to the plant, species sensitivity and bone type specificity (Barros et al. 1996).

Many researchers found that the increase in bone mass observed after $\mathrm{Sm}$ ingestion may be due to an increase in osteoid production by osteoblasts (Carrillo 1973, Dämmrich et al. 1975, Norrdin et al. 1975, Gimeno 1980). However, inhibition of bone resorption has also been reported in different animal species 
(Krook et al. 1975, Santos et al. 1976, Gimeno 1980, Riet-Correa et al. 1987).

Surprisingly, very few data has been published regarding the Sm effects on cartilage. Santos et al. (1976) have reported retarding effects in both articular and epiphyseal cartilages in growing rabbits. Similar observation were reported in guinea pigs (Ousavaplangchai 1972) and rats (Gimeno 1980). Microscopic and ultrastructural features have been widely studied in normal and rachitic cartilages (Appleton 1988). However, as far as we know, epiphyseal growth plate has not been ultrastructurally studied either in hypervitaminosis D nor in enzootic calcinosis.

The aim of this study was to describe the histological findings in bone tissue and in cartilage of the growth plate and to analyse the ultrastructural features of the growth plate abnormalities after a subacute $S m$ poisoning in rabbits.

\section{MATERIALS AND METHODS}

Plant material was collected from several areas of the Province of Buenos Aires, Argentina, and dried at $37^{\circ} \mathrm{C}$ for $48 \mathrm{~h}$. Leaves were separated from stems and milled to a fine powder. Four white New Zealand rabbits $(2-2.5 \mathrm{~kg} / \mathrm{bw})$ received $300 \mathrm{mg}$ of dry powdered leaves of $\mathrm{Sm}$ orally on daily basis during 9 days. The animals received a commercial diet (Cargill, Pilar, Córdoba, Argentina) containing a concentration of $0.87 \%$ and $0.78 \%$ of calcium and phosphorus, respectively. The grounded leaves were mixed with water and administered intragastrically with a flexible tube. Two rabbits received a placebo during 9 days and were used as controls. The body weight of each animal was recorded twice a week. Clinical signs were observed and recorded every day. The animals were carefully necropsied. Distal femur, proximal tibia and ribs, and primary and secondary spongiosa were processed for histology. Tissues were fixed in $10 \%$ buffered formalin, decalcified with EDTA (ethylenediaminetetracetic acid), embedded in paraffin, sectioned at $5 \mu \mathrm{m}$ and stained with haematoxylin and eosin.

For electron microscopy, samples from growth plate of proximal tibia were cut into small cubes of 2-3 mm, fixed in Karnovsky's solution (2.5\% glutaraldehyde and $2 \%$ paraformaldehyde PBS $0.1 \mathrm{M}, \mathrm{pH} 7.4$ ) containing $0.05 \%$ ruthenium red for $2 \mathrm{~h}$. Samples were then washed in buffer containing $0.05 \%$ ruthenium red, posfixed in $1 \%$ osmium tetroxide containing $0.05 \%$ ruthenium red, dehydrated in a gradient of ethanol $(50,70,80,90$ and $95 \%)$ and impregnated in propilen oxidize. Finally, all the samples were embedded in epoxi resin (Poly/Bed 812, Polysciences 18976-2590). Ultrathin sections were cut with a SuperNova ultramicrotome (Reichter-Jung, Austria) and observed using a transmission electronic microscope JEM-1200 FORMER II (JEOL Co. Ltd., Tokyo).

\section{RESULTS}

The Sm-poisoned rabbits showed anorexia, loss of weight and also diarrhoea and rhinitis. On macroscopic examination, small calcified plaques were observed in the entire length of the aorta. Microscopic calcifications, von Kossa positive, were seen in the aorta, heart and kidneys.

The histologic examination of the long bones revealed that $\mathrm{Sm}$-poisoned rabbits had an increase in bone resorption areas in the endosteal surface of the cortical bone (Fig. $1 \mathrm{~B}$ ) in comparison with control bones (Fig. $1 \mathrm{~A}$ ). An increase in bone resorption and in the surface covered by osteoblasts were also observed in the primary and secondary spongiosa of the trabecular bone compartment (Fig. $1 \mathrm{D}$ ) differing with what was observed in nonpoisoned rabbits (Fig. $1 \mathrm{C}$ ). Mesenchymal metaplasia was observed in the periosteum with the formation of cartilage (Fig. $1 \mathrm{E}$ ).

Growth plates were narrowed and showed an irregular pattern due to a focal or diffuse reduction in the number of chondrocytes in the proliferative and hypertrophic zones. Moreover, disorganized arrangement of chondrocytes and a shortening of the longitudinal septa in the calcified cartilage zone were also observed (Fig. $1 \mathrm{~F}$ ).

Ultrastructural studies revealed early degenerative changes in chondrocytes of the proliferative zone, and a reduction in the number and size of proteoglycan granules of the territorial and interterritorial areas in the hypertrophic zone of the cartilage of the growth plate (Fig. 2). The bones of control animals did not show alterations.

\section{DISCUSSION}

In the study, the growth plate was irregular and narrow due to a reduction in the number of chondrocytes of the proliferative and hyperthophic zones. This could be explained by an inhibitory effect of $1,25(\mathrm{OH})_{2} \mathrm{D}_{3}$ on cell division (Walters 1992). This feature was described in the skin of Sm-poisoned animals (Gimeno et al. 2000). The decrease in the concentration of ruthenium redpositive granules, particularly in the pericellular region of the chondrocytes was accompanied by an increase in matrix calcification. Ruthenium red-positive granules represent an accumulation of unmodified proteoglycan aggregated from which calcium ions are excluded and so preventing calcification (Appleton 1988). It has been reported that proteoglycans are completely desegregated prior to cartilage calcification (Campo \& Romano 1986, Yoshioka \& Yagi 1989).

The presence of cartilage in the subperiosteum of the ribs in $\mathrm{Sm}$-treated rabbits can also be explained by the direct effect of $1,25(\mathrm{OH})_{2} \mathrm{D}_{3}$ stimulus, since mesenchymal metaplasia has been frequently observed in enzootic calcinosis (Collier 1927, Worker \& Carrillo 1967, Done et al. 1976, Morris 1978, Barros et al. 1981, Tokarnia et al. 2000).

We have also described an increased bone remodeling in the secondary spongiosa. This finding could be explained by the calcinogenic effect of $S m$ that enhance bone resorption, by increasing the number and activity of osteoclasts as seen with $1,25(\mathrm{OH})_{2} \mathrm{D}_{3}$ (Baylink et al. 1973, Grise et al. 1990). Other researchers (Riet-Correa 1987, Barros et al. 1996), in contrast, showed that acute $\mathrm{Sm}$-poisoning produces a cytotoxical inhibition of osteocytes, osteoblasts and osteoclasts in cortical bone.

Differences in the bone response to $\mathrm{S} m$ have been observed both in vivo and in vitro. Even a dual effect have been reported in relation to the concentration of $\mathrm{Sm}$ purified extract: in vitro studies found a stimulatory effect on bone resorption at low concentrations and a clear inhibition at higher concentrations (Stern et al. 1978).

Vitamin D metabolites also modulate cell differentiation in cartilage. It has been demonstrated that $1,25(\mathrm{OH})_{2} \mathrm{D}_{3}$ promotes chondrocytes differentiation of chondrocytes along the endochondral differentiation cascade (Gerstenfeld et al. 1990). 

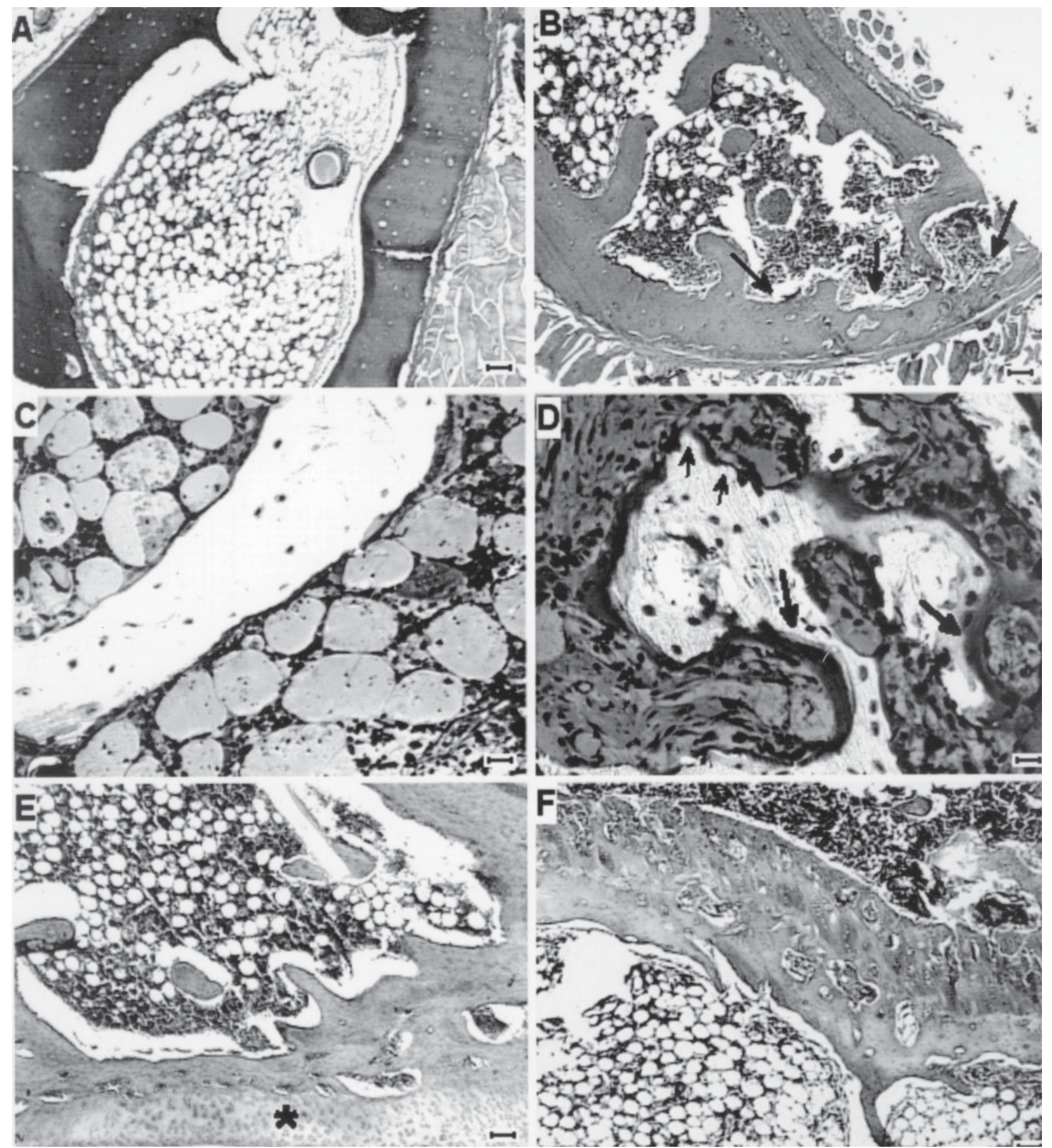

Fig. 1. Effects of subacute Solanum malacoxylon poisoning on different bone structures. (A) Transversal section of the mid-shaft of a rib in a control rabbit. HE, bar $100 \mu \mathrm{m}$. (B) Transversal section of the mid-shaft of a rib of a Sm-treated rabbit. Note the prominent eroded surfaces present at the endosteal envelope (arrows). HE, bar $100 \mu \mathrm{m}$. (C) Trabecular bone of a distal femur metaphysis. Control rabbits showed resting surfaces. Toluidine blue, bar $40 \mu \mathrm{m}$. (D) A significant increase in bone remodelling was observed in the Sm-poisoned rabbits. Note the eroded surfaces (small arrows), osteoclast surface, and the surfaces covered by osteoid tissue (large arrows). Toluidine blue, bar $40 \mu \mathrm{m}$. (E) Prominent areas of chondrocytes were observed in the periosteum of ribs of Sm-treated rabbits, just beneath its outer layer (*). HE, bar $40 \mu \mathrm{m}$. (F) Proximal tibia epiphyseal growth plate of a Sm-poisoned rabbit. The growth plate was irregular and narrow due to focal or diffuse reduction of proliferative and hypertrophic chondrocyte zones. The primary spongiosa appeared as a dense metaphyseal band of woven bone, and a reduction in secondary spongiosa development was also seen. HE, bar $40 \mu \mathrm{m}$. 

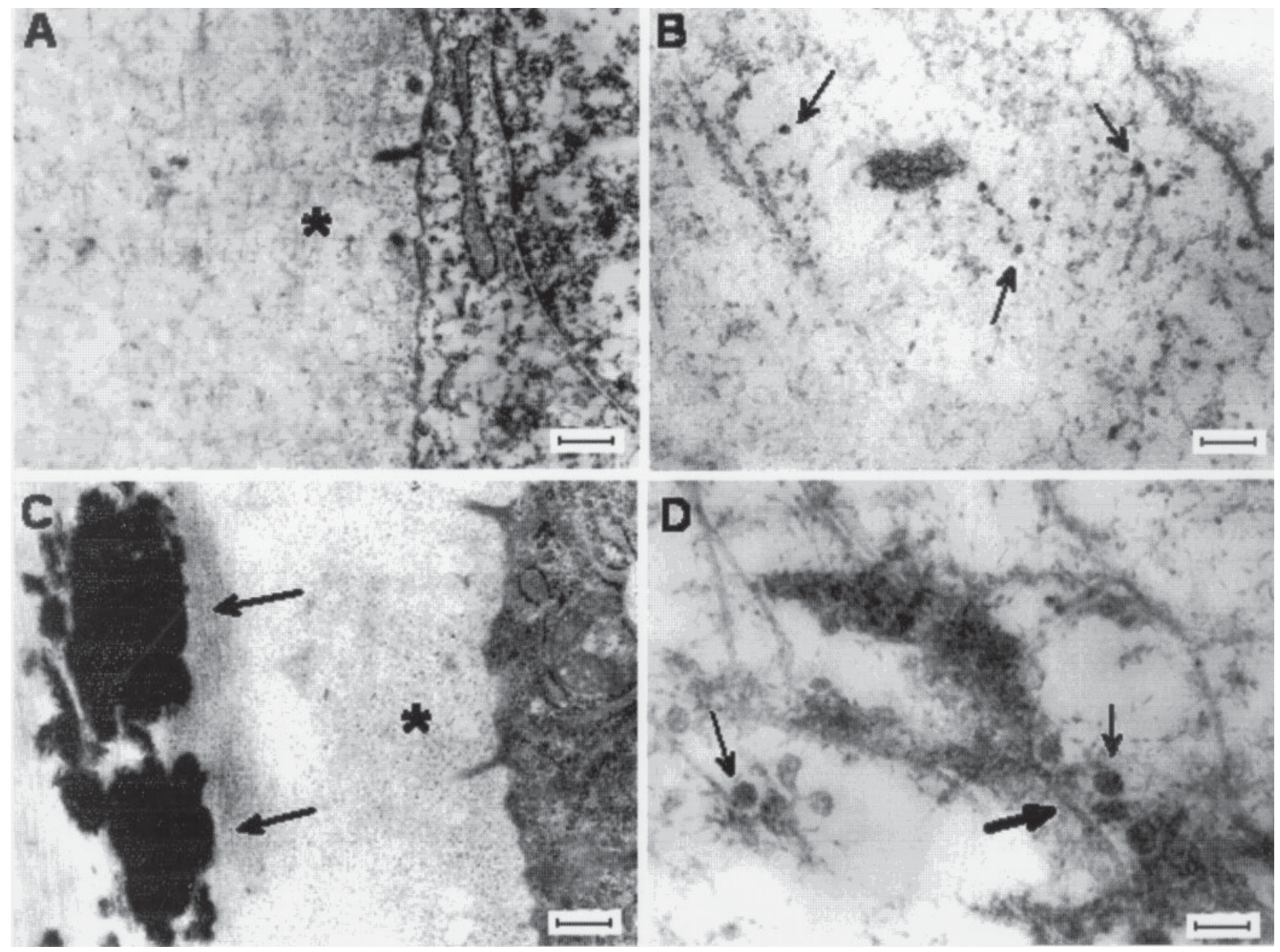

Fig. 2. Effect of subacute Solanum malacoxylon poisoning at ultrastructural level. (A) Hypertrophic chondrocytes of control rabbit growth plates. Note the small amount of ruthenium red positive granules in the pericellular region (\%). Bar 500nm. (B) High magnification of the territorial zone (*) from A. Note the calcium deposits associated with vesicles and collagen fibers (arrows). Bar $100 \mathrm{~nm}$. (C) Hypertrophic chondrocytes of Sm-poisoned rabbit growth plates. Note the increased amount of ruthenium red positive granules in the pericellular region (*) and calcium deposits forming large irregular masses in the territorial zone (arrows). Bar 500nm. (D) High magnification of the territorial zone (") showed in C. Note the increased amount of calcium deposits associated with vesicles (small arrows) and collagen fibers (large arrow). Bar 200nm.

Chondrocyte response to vitamin D metabolites depends on the state of differentiation. Chondrocytes located at the resting zone respond primarily to $24,25(\mathrm{OH})_{2} \mathrm{D}_{3}$, whereas chondrocytes located at the proliferative zone respond primarily to $1,25(\mathrm{OH})_{2} \mathrm{D}_{3}$. Vitamin $\mathrm{D}$ has direct effects on cartilage and is not mediated by changes in serum or extracellular calcium (Schwartz et al. 1988, Boyan et al. 1992). The $1,25(\mathrm{OH})_{2} \mathrm{D}_{3}$ has been shown to have a number of important functions in the endochondral bone formation cascade. It not only stimulates chondrocyte differentiation but also inhibits cell division in chondrocytes of both resting zone and growth zones (Schwartz et al. 1989).

The effects of $1,25(\mathrm{OH})_{2} \mathrm{D}_{3}$ on cell differentiation have been extensively studied in both normal and abnormal conditions, e.g. bone disease, psoriasis, and cancer (Clemens et al. 1983, Rice et al. 1992, Walters 1992, Bikle \& Pillai 1993). Changes in cell differentiation induced by calcinogenic plants have been analysed in skin, aorta and lung (Barros \& Gimeno 2000, Gimeno et al. 2000, 2004, Gomar et al. 2000, Portiansky et al. 2002).

Altogether, these data suggest that as occurs with $1,25(\mathrm{OH})_{2} \mathrm{D}_{3}$ (Bikle et al. 1990), Sm may induce different responses or effects, depending on exposure time to the plant, species sensitivity and bone type specificity.

Our data also suggest that the administration of Sm may induce a derangement of endochondral ossification by affecting cell differentiation in the epyphyseal growth plate and in the primary spongiosa. Alteration in cell differentiation during the intramembranous ossification may also be present because cartilage tissue was frequently observed beneath the outer layer of the periosteum.

Acknowledgements.- The authors would like to thank Mrs. Rosa Villegas for her technical assistance. Financial support was provided in part by grants from the "Agencia Nacional de Promoción Científica", the "Acade- 
mia Nacional de Agronomía y Veterinaria" and the "Consejo Nacional de Investigaciones Científicas (CONICET)”, Argentina. ELP and EJG are Research Career Members of CONICET.

\section{REFERENCES}

Appleton J. 1988. The ultrastructural distribution of proteoglycans in normal and rachitic growth cartilage from the mandibular condyle of the rat. Archs Oral Biol. 33: 379-381.

Barros S.S. \& Gimeno E.J. 2000. Cell differentiation and bone protein synthesis in the lung of sheep affected by spontaneous calcinosis. J. Comp. Pathol. 123:270-277.

Barros S.S., Russowski D. \& Grando S. 1996. Ultra-estructura das alteraçoes ósseas na intoxicaçao experimental por Solanum malacoxylon em coelhos. Pesq. Vet. Bras. 16:81-86.

Barros S.S., Tabone E., Dos Santos M., Andujar M. \& Grimaud J.A. (1981). Histopathological and ultrastructural alterations in the aorta in experimental Solanum malacoxylon poisoning. Virchow Archiv (Cell Pathol.) 35:167-175.

Baylink D., Sipe J., Wergedal J. \& Whitemore O. 1973. Vitamin D enhance osteocytic and osteoclastic bone resoption. Am. J. Physiol. 221:13451347.

Bikle D., Halloran P., McGalliard-Cone C. \& Morey-Holton E. 1990. Different responses of trabecular and cortical bone to $1,25(\mathrm{OH})_{2} \mathrm{D}_{3}$. Am. J. Physiol. 259:716-722.

Bikle D.D. \& Pillai S. 1993. Vitamin D, calcium, and epidermal differentiation. Endocr. Rev. 14:3-19.

Boyan B., Schwartz Z. \& Swain L.D. 1992. In vitro studies on the regulation of endochondral ossification by vitamin D. Crit. Rev. Oral Biol. Med. 3:1530 .

Campo R.D. \& Romano J.E. 1986. Changes in cartilage proteoglycans associated with calcification. Calcif. Tissue Int. 39:175-184.

Carrillo B.J. 1973. Efecto de la intoxicación de Solanum malacoxylon en el sistema óseo. Revta Investnes Agropec., INTA, 40:67-77.

Clemens, T.L., Adams, J.S., Horiuchi, B.A., Cho, H., Tsuchiya, Y., Matsuo, N., Suda, T. \& Holick, M.F. 1983. Interaction of 1,25-dihydroxyvitamin- $\mathrm{D}_{3}$ with keratinocytes and fibroblasts from skin of normal subjects and a subject with vitamin-D-dependent rickets type II: A model for study the mode of action of 1,25-dihydroxyvitamin- $D_{3}$. J. Clin. Endocr. Metab. 56:824830

Collier W.A. 1927. Zur Kenntnis als Enteque bezeichneten Krankheit der Rinder in der Provinz Buenos Aires. Zeitschr. Infektionskrankh. Parasit. Krankh. Hyg. Haust. 31:81-92.

Dämmrich K., Döbereiner J., Done S.H. \& Tokarnia C.H. 1975. Skelettveränderungen nach Vergiftungen mit Solanum malacoxylon bei Rindern. Zentralbl. Veterinärmed. Reihe A 22:313-329.

Döbereiner J. \& Dämmrich K. 1974. Skelettveränderungen bei Rindern nach Vergiftungen mit Solanum malacoxylon Sendtner. Verh. Dtsch. Ges. Pathol 58:323-326

Done S.H., Döbereiner J. \& Tokarnia C.H. 1976. Systemic connective tissue calcification in cattle poisoned by Solanum malacoxylon: a histological study. Brit. Vet. J. 132:28-38.

Esparza M.S., Vega M. \& Boland R.L. 1982. Synthesis and composition of vitamin D-3 metabolites in Solanum malacoxylon. Bioch. Bioph. Acta 719:633-640.

Gerstenfeld L.C., Kelly C.M. Von Deck M. \& Lian J.B. 1990. Effect of 1,25dihydroxyvitamin $\mathrm{D}_{3}$ on induction of chondrocyte maturation in culture: extracellular matrix gene expression and morphology. Endocrinol. 126:1599-1609.

Gimeno E.J. 1980. Estudio histopatológico de las alteraciones óseas en ratas carenciadas en vitamina D y ratas intoxicadas con Solanum malacoxylon. Analecta Vet. 12:61-108.

Gimeno E.J., Costa E.F., Gomar M.S., Massone A.R. \& Portiansky E.L. 2000. Effects of plant induced hypervitaminosis D on cutaneous structure, cell differentiation and cell proliferation in cattle. J. Vet. Med. A 47:201-211.

Gimeno E.J., Portiansky E.L., Gomar M.S., Costa E.F., Massone A.R., Alonso
C.R., Dallorso M.E. \& Barros S.S. 2004. Calcinosis in ruminants due to plant poisoning: Contributions on the pathogenesis. Chapter 12. In Acamovic T., Stewart C.S. \& Pennycott T.W. (ed.) Poisonous Plants and Related Toxins. CAB International (HB ISBN 085199 6140).

Gomar M.S., Portiansky E.L., Dallorso M.E., Barros S.S., Costa E.F. \& Gimeno E.J. 2000. Cell differentiation and bone protein synthesis in the aorta and lung induced by calcinogenic plants, p.435-438. In: Norman A.W., Bouillon R. \& Thomasset M. (ed.) Vitamin D Endocrine System: Structural, Biological, Genetics and Clinical Aspects. University of California Press, Davis.

Grise M., MacKay C. \& Popoll S. 1990. Effects of $1,25(\mathrm{OH})_{2} \mathrm{D}_{3}$ on osteoclast number and cytochemistry in normal and osteopetrotic rabbits. Am. J. Anat. 189:261-266.

Jubb K.V.F., Kennedy P.C. \& Palmer N. 1993. Pathology of Domestic Animals. 4th ed. Academic Press, San Diego.

Krook L., Wasserman R.H., Shively J.N., Tashjian A.H. Jr, Brokken T.D. \& Morton J.F. 1975. Hypercalcemia and calcinosis in Florida horses: implication of the shrub Cestrum diurnum, as the causative agent. Cornell Vet. 65:26-56.

Morris K.L.M. 1978. Plant induced calcinosis. Vet. Human Toxicol. 24:3448.

Norrdin R.W., Barros C.S.L., Queille ML, Carré M. \& Miravet L. 1975. Acute effects of Solanum malacoxylon on bone formation rates in growing rats. Calcif. Tissue Int. 28:239-243.

Okada K.A., Carrillo B.J. \& Tilley M. 1977. Solanum malacoxylon Sendtner: A toxic plant in Argentina. Econ. Botany 31:225-236.

Ousavaplangchai L. 1972. Vergleichende Untersuchungen zur Histopathologie der Intoxikation mit Vitamin $\mathrm{D}_{3}$ und Solanum malacoxylon beim Meerschweinchen. Dissertation, Wien.

Portiansky EL, Alonso CR, Costa EF \& Gimeno EJ. 2002. Collagenous and elastic system fibres in the aorta of cattle poisoned by Solanum glaucophyllum. Vet. Rec. 150:42-45.

Puche R.C. \& Bingley J.B. 1995. Calcinosis of Cattle in Argentina. First English edition. National University of Rosario Editors (ISBN No. 950-673112-8).

Rice R.H., Qin Q. \& Pilato A.L. 1992. Keratinocyte differentiation markers: Involucrin, transglutaminase, and toxicity. J. Natl Inst. Cancer Monogr. 13:87-91.

Riet-Correa F., Schild A.L., Méndez M.C., Wasserman R. \& Krook L. 1987. Enzootic calcinosis in sheep caused by the ingestion of Nierembergia veitchii (Solanaceae). Pesq. Agropec. Bras. 7:85-95.

Santos M.N., Nunes V.A., Nunes I.J., Barros S.S., Wasserman R.H. \& Krook L. 1976. Solanum malacoxylon toxicity: inhibition of bone resorption. Cornell Vet. 66:566-589.

Schwartz Z., Schlader D.L., Swain L.D. \& Boyan B.D. 1988. Direct effects of 1,25-dihydroxyvitamin $\mathrm{D}_{3}$ and 24,25 dihydroxyvitamin $\mathrm{D}_{3}$ on growth zone and resting zone chondrocyte membrane alkaline phosphatase and phospholipase- $A_{2}$, specific activities. Endocrinol. 123:2878-2884.

Schwartz Z., Schlader D.L., Ramirez V., Kennedy M.B. \& Boyan B.D. 1989. Effects of vitamin D metabolites on collagen production and cell proliferation of growth zone and resting zone cartilage cells in vitro. J. Bone Miner. Res. 4(2):199-207.

Stern P.H., Ness E.M \& DeLuca H.F. 1978. Responses of fetal bones to Solanum malacoxylon in vitro: A possible explanation of previous paradoxical results. Molec. Pharmacol. 14:357-365.

Tokarnia C.H., Döbereiner J. \& Peixoto P.V. 2000. Plantas Tóxicas do Brasil. Editora Helianthus, Rio de Janeiro, p.188-199.

Walters M.R. 1992. Newly identified actions of vitamin D endocrine system. Endocr. Rev. 13:719-764.

Wasserman R.H., Henion J.D., Haussler M.R. \& Mc Cain T.A. 1976. Calcinogenic factor in Solanum malacoxylon: evidence that it is 1,25-dihydroxyvitamin $D_{3}$-glycoside. Science 194:853-855.

Worker N.A. \& Carrillo B.J. 1967. 'Enteque seco', calcification and wasting in grazing animals in Argentina. Nature 215:72-74.

Yoshioka C \& Yagi T. 1989. Electron microscopic study of condylar cartilage of rat mandible stained with ruthenium red: proteoglycans and hypertrophic chondrocytes. J. Cranifac. Genet. Dev. Biol. 9:303-314. 